\title{
Differential adaptations in nursery seedlings from diverse Chilean provenances of Peumus boldus Mol.
}

\author{
Carlos R Magni ${ }^{(1)}$, Sergio E \\ Espinoza ${ }^{(2)}$, Emilio F Garrido ${ }^{(1)}$, \\ Rómulo E Santelices (2), \\ Antonio M Cabrera ${ }^{(2)}$
}

\begin{abstract}
Seed germination, seedling growth and biomass allocation of the endemic species Peumus boldus Mol. (Boldo) were studied in four provenances (two northern and two southern provenances) from central Chile. Seeds collected from five different mother plants for each provenance were sowed in plastic pots and placed in an ambient nursery. Germinated seeds were transplanted to $130-\mathrm{mL}$ containers and cultivated under nursery conditions during one growing season. Germination capacity, seed weight, morphological traits of seedlings (root collar diameter, height, number of leaves, foliar area, root length), their biomass allocation pattern (dry mass of leaves, shoots and roots) and survival were analyzed. Results showed significant differences among provenances and mother plants for most traits. Northern provenances showed slower germination, smaller size, higher root biomass, lesser leaf area, and higher survival, while seedlings from southern provenances were taller, with more body mass, larger leaf area and lower root biomass. We concluded that northern provenances of Peamus boldus are more tolerant to drought and therefore are suitable for ecological restoration of drought-prone Mediterranean sites, while the use of southern provenances must be restricted to restoration of more humid environments.
\end{abstract}

Keywords: Boldo, Habitat Differentiation, Adaptation, Seed Provenances, Seedling Growth, Survival

\section{Introduction}

In the last decades, several studies reported the increase of land degradation and desertification in Mediterranean ecosystems (Hill et al. 2008, Moreira et al. 2011, Schulz et al. 2010). Mediterranean plants are well adapted to summer drought, though such adaptation may not be sufficient to ensure plant regeneration under extreme land degradation scenarios (e.g., wildfires - Pausas et al. 2008). Indeed, water stress is a major cause of failure in ecological restoration of Mediterranean ecosystems (Mendoza et al. 2009). According to climate change predictions, the frequency and intensity of drought is expected to increase in Mediterranean regions (CONA MA 2006, IPCC 2007). This calls for studies focused on the ecology of species and their

intra-specific variability in order to better understand their adaptability to the predicted changes and their suitability for ecological restoration purposes.

Peumus boldus Mol. (Boldo) is a sclerophyllous evergreen shrub native to Chile between $30^{\circ}$ to $41^{\circ} \mathrm{S}$ and growing in plant communities of the Mediterranean region in central Chile (Hoffmann \& Alliende 1984). This species has several characteristics that make it an interesting case study for ecological restoration protocols, namely, a higher resistance to drought compared with other Mediterranean species, surviving in sites with less than $200 \mathrm{~mm}$ of annual precipitation (Cabello \& Donoso 2013). Its perennial leaves are used in medicine for their digestive, choleretic, and liver-protection properties (Del Valle et al.
(1) Departamento de Silvicultura, Facultad de Ciencias Forestales y de la Conservación de la Naturaleza, Universidad de Chile, Avenida Santa Rosa 11315, La Pintana, Santiago (Chile); (2) Centro de Desarrollo para el Secano Interior, Facultad de Ciencias Agrarias y Forestales, Universidad Católica del Maule, Avenida San Miguel 3605, Talca (Chile)

@ Sergio E Espinoza (espinoza.sergio@gmail.com)

Received: Oct 02, 2015 - Accepted: Oct 20, 2015

Citation: Magni CR, Espinoza SE, Garrido EF, Santelices RE, Cabrera AM (2016). Differential adaptations in nursery seedlings from diverse Chilean provenances of Peumus boldus Mol. iForest 9: 409-413. - doi: 10.3832/ifor1893-008 [online 2016-01-29]

Communicated by: Gianfranco Minotta
2005), and this has generated a high pressure over the native forests. Furthermore, Boldo seeds have low germination rates (19-44\% - Cabello \& Donoso 2013) due to the dormancy imposed by the essential oils of the pericarp. Botti \& Cabello (1990) pointed out that if Boldo seeds are sown during fall or winter, they will only germinate during the winter of the next year, being the embryo still immature; therefore, seeds must be collected in spring and sown immediately.

Despite the strong geographical isolation of southern provenances from the northern ones (Cabello \& Donoso 2013), information about the genecological differentiation of Peumus boldus is scarce. Vogel et al. (1997) analyzed alkaloid and essential oil production in three different Boldo populations from central Chile, finding that northern provenances had significantly higher essential oil content and alkaloid concentration. Moreover, the available information on the variability of germination and seedling growth among provenances is limited. Germination was reported to greatly vary among populations (Bischoff et al. 2006b).

It is known that provenances growing in Mediterranean environments show reduced leaf area as one of the key traits to withstand water deficit (Baldocchi \& Xu 2007). Contrastingly, provenances from more mesic environments have elongated and large leaves and are restricted to humid or subhumid sites mainly in mild 


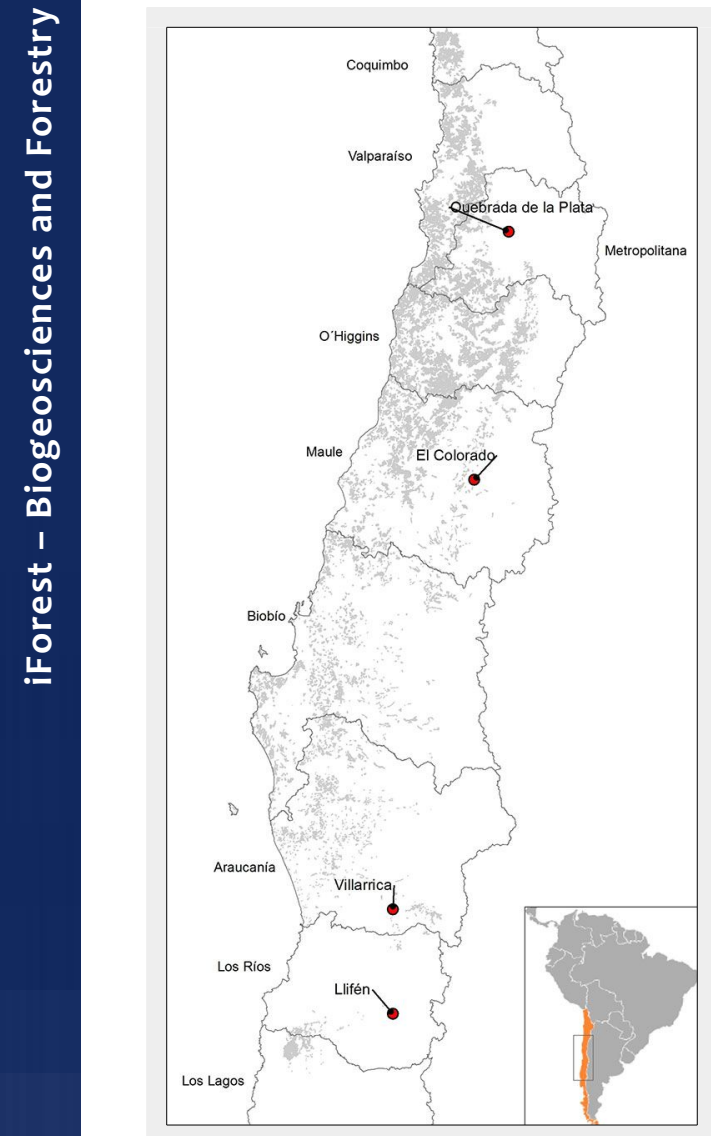

Fig. 1 - Location of the four provenances of Peumus boldus selected for seed collection (red circles).

coastal areas (e.g., the "ilex" morphotype of Quercus ilex - Lumaret et al. 2002). According to the theory of specialization (Lortie \& Aarssen 1996), genotypes adapted to favorable environments present superior performances in these environments as compared with those adapted to drought, but this is reduced when conditions are limiting, which results in a high phenotypic plasticity. It is also known that germination requirements of different species are often related to specific adaptation to their habitat (Meyer et al. 1995). As a consequence, seeds collected from different parts of the species' range often vary in their germination requirements.

In Chile, a limited number of studies have been carried out in P. boldus on the effect of provenance and mother plant in seed germination and seedling development.
The aim of the present study was to analyze the effect of seed provenance and mother plant on the germination and short-term development of $P$. boldus. The wide distribution of $P$. boldus and the heterogeneity of the environments colonized suggest a high phenotypic plasticity of the species in terms of morphology. We tested the hypothesis that seedlings from northern provenances are more adapted to xeric environments, while southern provenances have adaptation mechanisms suitable for more humid environments.

\section{Material and methods}

\section{Site selection and seed collection}

Four provenances of $P$. boldus were selected in mainland Chile, at distances of at least $150 \mathrm{~km}$, along a latitudinal gradient (Fig. 1). Two seed sources from central Chile represented northern provenances (Quebrada de la Plata and Colorado), and two seed sources from the south represented southern provenances (Villarica and Llifén). A general description of the seed collection sites is given in Tab. 1. Ripe fruits of trees were harvested at the four collection sites between December 2006 and February 2007. The collection date varied since the rate of seed maturation differed between provenances (early December in the north, late February in the south). For each provenance, five dominant or codominant mother trees with clear bole, well developed crown, good health condition and abundant fruits were randomly selected at a minimum distance of $100 \mathrm{~m}$. We harvested 500 fruits per mother tree, evenly distributed over the canopy. Fruits were then depulped, seeds were washed and sown immediately after collection, according to Botti \& Cabello (1990).

\section{Seed germination variability}

Seeds were soaked in distilled water for 24-48 $\mathrm{h}$ and those floating were discarded. Seeds were set to germinate in 1-liter plastic pots containing a mixture of sand and topsoil 1:1 $(\mathrm{v} / \mathrm{v})$. Four plastic pots were used as replicates and a total of 100 seeds per mother plant were sown in each pot. Seeds were then placed under nursery conditions (average temperature $23.5{ }^{\circ} \mathrm{C}, 60-80 \%$ relative humidity). The nursery was located at the University of Chile, Santiago $\left(33^{\circ} 34^{\prime}\right.$ $05^{\prime \prime} \mathrm{S}, 70^{\circ} 37^{\prime} 55^{\prime \prime} \mathrm{W}, 611 \mathrm{~m}$. a.s.l) with cli- matic conditions similar to those of the Quebrada de la Plata provenance. Germination was monitored two times per week and recorded when the radicle emerged from the testa. The germination capacity (GC) was expressed as the proportion of the total number of germinated seeds out of sown seeds. Seed weight (SW) was estimated according to ISTA (2006) and expressed as the average weight of 1000 seeds. As $P$. boldus has germination difficulties due the pericarp, seeds were sown immediately after harvesting, which led to different sowing dates. To avoid possible biases due to differences in sowing date, the number of days elapsed since sowing until full germination (radicle $>5 \mathrm{~mm}$ showing geotropism - DG) was registered for every provenance.

\section{Seedling growth}

The germinated seeds were transferred to $130 \mathrm{~mL}$ containers (BASF ${ }^{\oplus}$, Santiago, Chile) filled with a mixture of sand and topsoil 1:1 $(\mathrm{v} / \mathrm{v})$. No fertilizer was added to the substrate. The experimental setup comprised four provenances, five mother plants per provenance, five replicates of 7 seedlings per replicate, totaling 700 seedlings $(4 \times 5 \times$ $5 \times 7=700$ seedlings). The seedlings were watered to field capacity and grown under nursery conditions during one growing season. Seedlings were protected by a 50\% shading plastic mesh (Raschel ${ }^{\circledR}$, Santiago, Chile).

Total height $(\mathrm{H}, \mathrm{cm})$, root collar diameter $(\mathrm{D}, \mathrm{mm})$ and number of leaves (NL) of all seedlings were recorded, as well as their survival in percentage (SUR). Survival was measured according to a categorical scale $(1=$ alive, $0=$ dead). At the end of the first year of growth, seedlings were cut and separated into three fractions: leaves, stems and roots. The dry weight of each fraction was determined after oven drying at $65^{\circ} \mathrm{C}$ for $48 \mathrm{~h}$. The relative biomass was then determined and the following variables were recorded: leaf dry weight (LDW), stem dry weight (SDW), root dry weight (RDW) and total dry weight (TDW). Root weight ratio (RWR $=$ RDW/TDW) and leaf weight ratio $(L W R=L D W / T D W)$ were also determined. Foliar area of seedlings (FA, $\mathrm{cm}^{2}$ ) was also measured using a common desk-top scanner (Hewlett-Packard ${ }^{\circledast}, \mathrm{Cu}$ pertino, CA), and the surface of all leaves measured using a digital planimeter (Ta-

Tab. 1 - Location, Köppen climate classification, mean annual temperature and mean total precipitation of the four collection sites.

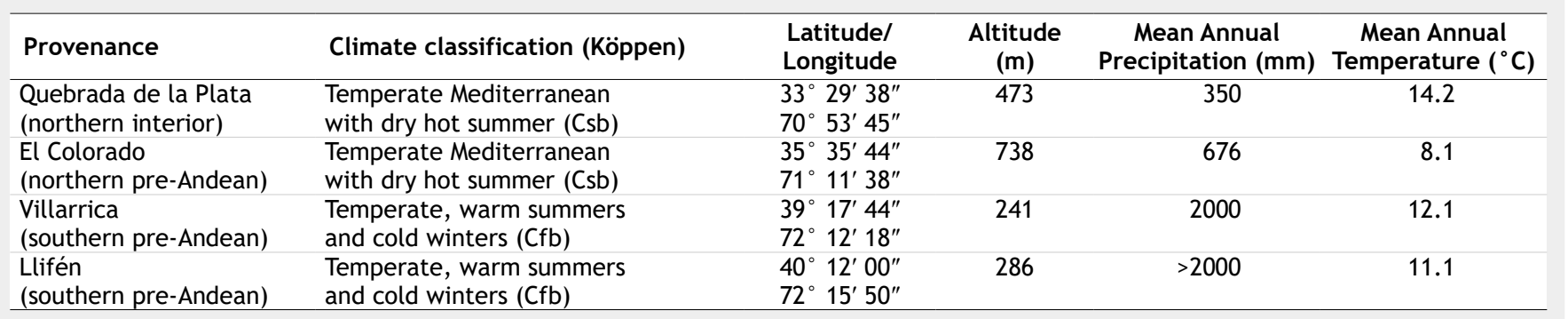


maya ${ }^{\circledR}$, Tokyo, Japan). Roots length ( $R L$, $\mathrm{cm}$ ) was also measured as the distance from the root collar to the top of the tap root.

\section{Statistical analysis}

All traits were analyzed by 2-Way ANOVA using a nested design, i.e., provenance as a fixed factor and the mother plant as the random nested factor within provenance. The general linear model approach (GLM) was used, with type III sum of squares. Comparisons between groups for categorical variables (i.e., SUR) were done using a Chi-square test. Tukey's HDS post-hoc tests were carried out when significant provenance and mother plant differences were detected $(\alpha=0.05)$. The SPSS ${ }^{\circledR}$ v.18 software (IBM, New York, USA) was used for all statistical analyses.

\section{Results}

\section{Variability in seed germination}

The overall mean germination capacity (GC) of P. boldus seeds was low (Tab. 2). However, significant differences in GC among mother plants within provenances were found. For example, the mean germination capacity in the Colorado and Llifén provenances differed by more than $100 \%$. Seed weight was different among both provenances and mother plant; however, the germination of small seeds $(<650 \mathrm{mg})$ was similar to that of large seeds ( $>900$ $\mathrm{mg}$ ). Moreover, we found significant differences among provenances in the germination time (i.e., the number of days elapsed from sowing to the emergence of the radicle - DG). Indeed, northern provenances germinated 37 days later than southern provenances.

\section{Seedling development}

Morphological traits and survival were different at the provenance and mother plant levels for most traits under consideration (Tab. 3). Seedlings from the southern provenances (Villarrica and Llifén) were taller and with thicker diameters than those from the northern provenances; however, the highest survival rate was found in the latter provenances (Colorado). Significant differences in leaf number and morphology were also found. Northern provenances showed smaller leaves as compared with southern ones, which had a lesser number of larger leaves. Regarding root anatomy, significant differences were also observed at population and mother plant levels. Seedlings from northern provenances (Quebrada de la Plata) exhibited longer roots as compared to southern provenances (Villarica and Llifén).

\section{Biomass allocation}

In general, there was shift in biomass allocation from northern to southern provenances, with the northernmost provenance seedlings (Quebrada de la Plata) having less body mass (TDW) and allocating a

Tab. 2 - Main effects on seed parameters of P. boldus tested through 2-way ANOVA using provenance (Prov) as fixed factor and mother plant (MP) as a random factor nested within provenance. Means \pm standard errors are reported. (GC): Germination capacity; (SW): average weight of 1000 seeds; (DG): days elapsed since sowing to radicle emergence. $\left(^{*}\right): p<0.05 ;(n s)$ : non-significant.

\begin{tabular}{lcccccc}
\hline \multirow{2}{*}{ Trait } & $\begin{array}{l}\text { Northern } \\
\text { Provenances }\end{array}$ & \multicolumn{3}{c}{$\begin{array}{l}\text { Southern } \\
\text { Provenances }\end{array}$} & \multicolumn{3}{c}{$\begin{array}{l}\text { Main effects } \\
\text { of factors }\end{array}$} \\
\cline { 2 - 7 } & $\begin{array}{c}\text { Quebrada } \\
\text { de la Plata }\end{array}$ & Colorado & Villarica & Llifén & Prov & MP(Prov) \\
\hline GC (\%) & $3.66 \pm 0.96$ & $5.78 \pm 1.66$ & $3.78 \pm 0.92$ & $2.70 \pm 0.64$ & ns & $*$ \\
SW (g) & $93.8 \pm 16.4$ & $62.0 \pm 4.50$ & $64.4 \pm 2.30$ & $77.8 \pm 4.55$ & $*$ & $*$ \\
DG (days) & $165 \pm 3.2$ & $167 \pm 4.1$ & $131 \pm 2.6$ & $126 \pm 3.3$ & $*$ & ns \\
\hline
\end{tabular}

Tab. 3 - Main effects in morphological traits and survival of $P$. boldus tested through 2way ANOVA using provenance (Prov) as fixed factor and mother plant (MP) as a random factor nested within provenance. Means \pm standard errors are reported. $(\mathrm{H})$ : total seedling height; (D): root collar diameter; (NL): number of leaves; (SUR): survival; $(R L)$ : root length; $(F A)$ : foliar area. $\left(^{*}\right): p<0.05 ;(n s)$ : non-significant.

\begin{tabular}{lrrrrrr}
\hline Trait & $\begin{array}{l}\text { Northern } \\
\text { Provenances }\end{array}$ & \multicolumn{3}{c}{$\begin{array}{l}\text { Southern } \\
\text { Provenances }\end{array}$} & \multicolumn{2}{c}{$\begin{array}{l}\text { Main effects } \\
\text { of factors }\end{array}$} \\
\cline { 2 - 7 } & $\begin{array}{l}\text { Quebrada } \\
\text { de la Plata }\end{array}$ & Colorado & Villarica & Llifén & Prov MP(Prov) \\
\hline $\mathrm{H}(\mathrm{cm})$ & $6.65 \pm 0.19$ & $7.56 \pm 0.19$ & $9.15 \pm 0.28$ & $8.79 \pm 0.26$ & $*$ & $*$ \\
D $(\mathrm{mm})$ & $1.65 \pm 0.04$ & $1.71 \pm 0.04$ & $1.81 \pm 0.04$ & $2.01 \pm 0.05$ & $*$ & $\mathrm{~ns}$ \\
NL & $10.94 \pm 0.47$ & $9.57 \pm 0.26$ & $8.28 \pm 0.27$ & $9.77 \pm 0.33$ & $*$ & $*$ \\
SUR $(\%)$ & $64.16 \pm 7.18$ & $71.18 \pm 5.43$ & $42.90 \pm 5.76$ & $54.70 \pm 6.28$ & $*$ & $*$ \\
RL $(\mathrm{cm})$ & $5.56 \pm 0.29$ & $4.95 \pm 0.21$ & $4.80 \pm 0.20$ & $5.22 \pm 0.30$ & $*$ & $*$ \\
FA $\left(\mathrm{cm}^{2}\right)$ & $10.80 \pm 0.61$ & $14.82 \pm 0.75$ & $15.89 \pm 0.89$ & $17.92 \pm 1.02$ & $*$ & $*$ \\
\hline
\end{tabular}

Tab. 4 - Main effects in biomass traits of $P$. boldus tested through 2-Way Analysis of Variance (ANOVA) using provenance (Prov) as fixed factor and mother plant (MP) as a random factor nested within provenance. Mean \pm standard errors are reported. (LDW): leaf dry weight; (SDW): shoot dry weight; (RDW): root dry weight; (TDW): total dry weight; (RSR): root to shoot ratio; (RWR): root weight ratio; (LWR): leaves weight ratio. $\left(^{*}\right)$ : $p<0.05 ;(n s)$ : non significant.

\begin{tabular}{lcccccc}
\hline & $\begin{array}{l}\text { Northern } \\
\text { Provenances }\end{array}$ & \multicolumn{3}{c}{$\begin{array}{l}\text { Southern } \\
\text { Provenances }\end{array}$} & \multicolumn{2}{c}{$\begin{array}{l}\text { Main effects } \\
\text { of factors }\end{array}$} \\
\cline { 2 - 7 } & $\begin{array}{c}\text { Quebrada } \\
\text { de la Plata }\end{array}$ & Colorado & Villarica & Llifén & Prov & MP(Prov) \\
\hline LDW (mg) & $0.14 \pm 0.00$ & $0.22 \pm 0.01$ & $0.20 \pm 0.01$ & $0.23 \pm 0.01$ & $*$ & $*$ \\
SDW (mg) & $0.05 \pm 0.00$ & $0.06 \pm 0.00$ & $0.07 \pm 0.00$ & $0.08 \pm 0.00$ & ns & $*$ \\
RDW (mg) & $0.63 \pm 0.05$ & $0.88 \pm 0.07$ & $0.60 \pm 0.04$ & $0.83 \pm 0.07$ & $*$ & $*$ \\
TDW (mg) & $0.82 \pm 0.02$ & $1.16 \pm 0.02$ & $0.87 \pm 0.02$ & $1.14 \pm 0.03$ & $*$ & $*$ \\
RWR & $0.77 \pm 0.00$ & $0.76 \pm 0.00$ & $0.69 \pm 0.00$ & $0.73 \pm 0.00$ & $*$ & $*$ \\
LWR & $0.17 \pm 0.00$ & $0.19 \pm 0.00$ & $0.23 \pm 0.00$ & $0.20 \pm 0.00$ & $*$ & $*$ \\
\hline
\end{tabular}

higher proportion of the total mass to belowground organs (RWR). Contrastingly, the southernmost provenance seedlings (Llifén) were taller and allocated a larger proportion of the total mass to leaves (LWR - Tab. 4). No differences in SDW were observed among provenances.

\section{Discussion}

\section{Seed germination}

In this study, the germination of P. boldus seeds was highly variable among mother plants within provenances, while its variation among provenances was not significant. The variability of seed germination is often interpreted as reflecting adaptations to specific ecological conditions (Grime et al. 1981, Nishitani \& Masuzawa 1996). Obviously, the environmental characteristics of the microsite occupied by a seed may strongly influence its probability of germination; however, the environmental conditions experienced by mother trees in the previous generation may also affect the germination of seeds (Roach \& Wulff 1987, Baskin \& Baskin 2014). Small differences in local site conditions, such as substrate type, soil humidity etc., cannot be excluded even when seeds are collected in the neighborhood. Several studies have shown a small-scale adaptation to such local habitat differentiation (Lenssen et al. 2004, Bischoff et al. 2006a), which may reduce the 
correlation between population differentiation and geographical distance.

In this study, we found no differences in seed germination capacity among different $P$. boldus provenances from a wide latitude gradient, while all the variation was attributed to differences among individual mother trees. Intra-population variability in germination is common in forest tree populations (Baskin \& Baskin 2014) and might correspond to genetic factors (Van Der Vegte 1978) as well as environmental variability during seed ripening (Meyer \& Allen 1999). In addition, seeds collected from different individuals of the same population also display large differences in germination, which supports the hypothesis that individual mother tree genotype also plays an important role in seed germination. Indeed, an attempt was made to minimize microsite-specific environmental differences by collecting seeds only from healthy individuals growing under similar conditions in the field. Nonetheless, the observed differences in germination capacity may be interpreted as mainly due to maternal effects, i.e., to genetic differences of the sampled trees. However, a complete ecological understanding of the variation in $P$. boldus seed germination requires a multiple generation study.

Another possible explanation of the large within-population variation observed in seed germination could be related to differences in fruit ripening among mother trees. As a general rule, fruits should be collected only after the seeds have reached the full maturity (Bonner \& Karrfalt 2008). This aspect has been poorly investigated in $P$. boldus. According to Muñoz (1986) the germination capacity of this species diminishes when the fruit is overripe; however, full seed maturity is not easily detectable, as the fruit color is widely used as an indicator of seed maturity. As mentioned above, we sowed $P$. boldus seeds immediately after fruit collection to avoid changes in their germination responses due to dry storage at room temperatures (Baskin \& Baskin 2014). However, differences in seed dormancy due to their different maturity cannot be excluded.

Different seed dormancy levels may also reflect differences in germination length, in terms of days elapsed since sowing until the radicle emerge (DG). In our study, significant differences in DG were found among geographically distinct provenances of the species. The northern Colorado provenance had the higher DG, which could be related to the higher elevation and lower mean annual temperature of the site (700-800 $\mathrm{m}$ and $8.1^{\circ} \mathrm{C}$, respectively). A longer delay in seed germination with increasing altitude and decreasing temperature may be the result of the increased susceptibility to unfavorable conditions during flowering and seed development. Moreover, seeds from this provenance were the smallest, indicating a lower endosperm content and thus lesser source of nutrient available for the embryo, which may defer the initiation of germination. Indeed, it has been reported that small seeds usually emerge more slowly (Tripathi \& Khan 1990). It is noteworthy to mention that the northernmost provenance (Quebrada de la Plata), characterized by large seeds sown three months earlier than southern provenances, showed a slower germination and yielded smaller seedlings with less body mass at the end of the experiment. This provenance seems to be adapted to the harsh conditions of the collection site, characterized by a low annual precipitation. Thus, it could be hypothesized that a delayed seed germination might represent an adaptation strategy to escape unfavorable conditions.

\section{Seedling development and biomass allocation}

We found a strong differentiation in seedling growth and biomass (both above- and belowground) among all the four provenances tested. The northernmost provenance site (Quebrada de la Plata) is characterized by a Mediterranean climate with low precipitation; accordingly, its seedlings showed the lowest foliar area (FA), which suggests a higher growth potential under low water availability, as a smaller transpiration surface may reduce the desiccation risk. Results of the present study are in line with findings of Doll et al. (2005) who analyzed three provenances of $P$. boldus in central Chile and found that the Mediterranean provenance had more leaf rolling than Coastal provenances. Leaf rolling has been proposed to be an effective mechanism in decreasing the transpiration rate of plants experiencing water deficit (O’Toole \& Cruz 1979, Kadioglu \& Terzi 2007).

On the other hand, southern provenances showed a lower survival rate when growing in a Mediterranean climate (as at the nursery in Quebrada de la Plata). According to the theory of specialization (Lortie \& Aarssen 1996), genotypes adapted to favorable environmental conditions exhibit superior performances in these environments, but the opposite occurs when conditions become limiting. In this study, seedlings from southern provenances showed performances consistent with this theory. In the xeric environment of the nursery, they grew more (higher $\mathrm{H}$ and TDW) and likely had an overall higher transpiration (as inferred from the superior FA, LDW and LWR), which clearly reduced survival. These provenances grow well in sites with more than $2000 \mathrm{~mm}$ annual precipitation, while in Quebrada de la Plata rainfall was only $350 \mathrm{~mm}$.

Although based on a nursery experiment with no field validation, our results revealed some important consequences in the field of restoration ecology. The introduction of $P$. boldus southern provenances in sites with a more Mediterranean climatic characteristics, as in the northern part of the species' range, may result in poor adaptation. Native plant species are routinely planted or sown in ecological restoration projects, but successful establishment and survival often depend on where and how seeds are collected (Vander Mijnsbrugge et al. 2010). Our results highlights the importance of using seeds from locally adapted individuals of $P$. boldus in Mediterranean restoration projects, as local populations often show better performances as compared with non-local genotypes. Southern provenances of $P$. boldus showed several characteristics typical of genotypes non-tolerant to drought (i.e., taller, with more body mass, larger leaf area and less root biomass), thus their use in restoration projects in drought-prone Mediterranean sites should be avoided. This is particularly important in regions such as Chile, where the Mediterranean environments are expected to shift southward as a consequence of the global climate change.

\section{Conclusions}

Provenance played a significant role in the early development of seedlings of $P$. boldus, highlighting the importance of the choice of suitable seed sources in ecological restoration plans. Northern provenances showed higher survival in comparison with the southern provenances. In addition, seedlings of the provenance from the driest site allocated more biomass to roots and less leaf dry weight, which suggest their adaptation to drought-prone Mediterranean ecosystems. On the other hand, the southern provenance seems to be more adapted to humid environments.

\section{Acknowledgements}

The authors gratefully acknowledge Dr. Anne Bliss from the University of Colorado at Boulder (CO, USA) who provided helpful criticism of the manuscript.

$C R$ conceived the study, organized the seed collection and reviewed the final manuscript; SE carried out the data analysis, and wrote an earlier draft and the final version of the manuscript; EG carried out the seed collection and the nursery trial; RS contributed with ideas and comments on the methodology of an earlier draft of the manuscript; AC commented the final draft of the manuscript.

\section{References}

Baldocchi DD, Xu L (2007). What limits evaporation from Mediterranean oak woodlands - the supply of moisture in the soil, physiological control by plants or the demand by the atmosphere? Advances in Water Resources 30: 21132122. - doi: 10.1016/j.advwatres.2006.06.013 Baskin CC, Baskin JM (2014). Seeds ecology, biogeography, and evolution of dormancy and germination. Academic Press, San Diego, CA, USA, pp. 1600.

Bischoff A, Crémieux L, Smilauerova $M$, Lawson C, Mortimer S, Dolezal J, Lanta V, Edwards AR, Brook AJ, Macel M, Leps J, Steinger T, MüllerSchärer H (2006a). Detecting local adaptation 
in widespread grassland species - the importance of scale and local plant community. Journal of Ecology 94: 1130-1142. - doi: 10.1111/j.13652745.2006.01174.x

Bischoff A, Vonlanthen B, Steinger T, MüllerSchärer H (2006b). Seed provenance matters effects on germination of four plant species used for ecological restoration. Basic and Applied Ecology 7: 347-359. - doi: 10.1016/j.baae.20 05.07.009

Bonner FT, Karrfalt RP (2008). The woody plant seed manual. Agriculture Handbook 727, USDA Forest Service, Government Printing Office, Washington, DC, USA, pp. 1228. [online] URL: http://books.google.com/books?id=ZnBRmdUU -3UC

Botti CG, Cabello A (1990). Anatomía y desarrollo de flores, frutos y semillas de boldo (Peumus boldus Mol.) [Anatomy and development of flowers, fruits and seeds of Boldo (Peumus boldus Mol.)]. Ciencia e Investigación Agraria 4: 49-6o. [in Spanish]. [online] URL: http://bos ques.ciren.cl:8080/handle/123456789/29

Cabello A, Donoso C (2013). Peumus boldus (Molina) Johnston. Boldo, Folo. Familia: Monimiaceae [Peumus boldus (Molina) Johnston. Boldo, Folo. Family: Monimiaceae]. In: “Las Especies Arbóreas de los Bosques Templados de Chile y Argentina. Autoecología" (Donoso C ed). Marisa Cuneo Ediciones, Valdivia, Chile, pp. 510-515. [in Spanish].

CONAMA (2006). Estudio de la variabilidad climática en chile para el Siglo XXI. Informe Final Texto [Study of the climatic variability in Chile for the XXI Century. Final Report]. Departamento de Geofísica Facultad de Ciencias, Físicas y Matemáticas, Universidad de Chile, Santiago, Chile, pp. 71. [in Spanish].

Del Valle JM, Rogalinski T, Zetzl C, Brunner G (2005). Extraction of boldo (Peumus boldus M.) leaves with supercritical $\mathrm{CO}_{2}$ and hot pressurized water. Food Research International 38: 203-213. - doi: 10.1016/j.foodres.2004.09.010 Doll U, Aedo D, Lopez P (2005). Caracterización morfológica de tres procedencias de boldo (Peumus boldus) en una plantación joven de 6 años [Morphological characterization of three provenances of Boldo (Peumus boldus) in a 6year-old plantation]. Bosque 26: 45-54. [in Spanish]. [online] URL: http://www.scielo.cl/scielo. php?pid=S0717-92002005000300005\&script=sC i_arttext

Grime JP, Mason G, Curtis AV, Rodman J, Band SR, Mowforth MAG, Neal AM, Shaw S (1981). A comparative study of germination characteristics in a local flora. Journal of Ecology 69: 1017-
1059. - doi: 10.2307/2259651

Hill J, Stellmes M, Udelhoven T, Röder A, Sommer S (2008). Mediterranean desertification and land degradation: mapping related land use change syndromes based on satellite observations. Global and Planetary Change 64: 146-157. - doi: 10.1016/j.gloplacha.2008.10.005

Hoffmann AJ, Alliende MC (1984). Interactions in the patterns of vegetative growth and reproduction in woody dioecious plants. Oecologia 61: 109-114. - doi: 10.1007/BF00379095

IPCC (2007). Climate change 2007: the physical science basis. Contribution of Working Group I to the fourth Assessment Report of the Intergovernmental Panel on Climate Change (Solomon S, Qin D, Manning M, Chen Z, Marquis M, Averyt KB, Tignor M, Miller HL eds). Cambridge University Press, New York, USA, pp. 996.

ISTA (2006). International rules for seed testing (2006 edn). International Seed Testing Association - ISTA, Bassersdorf, Switzerland. [online] URL: http://www.seedtest.org/en/international -rules-_content---1--1083.html

Kadioglu A, Terzi R (2007). A dehydration avoidance mechanism: leaf rolling. The Botanical Review 73: 290-302. - doi: 10.1663/0006-8101 (2007)73[290:ADAMLR]2.0.CO;2

Lenssen JPM, Van Kleunen $M$, Fischer $M$, De Kroon H (2004). Local adaptation of the clonal plant Ranunculus reptans to flooding along a small-scale gradient. Journal of Ecology 92: 696-706. - doi: 10.1111/j.0022-0477.2004.00895.x Lortie CJ, Aarssen LW (1996). The specialization hypothesis for phenotypic plasticity in plants. International Journal of Plant Sciences 157: 484-487. - doi: 10.1086/297365

Lumaret R, Mir C, Michaud H, Raynal V (2002). Phylogeographical variation of chloroplast DNA in holm oak (Quercus ilex L.). Molecular Ecology 11: 2327-2336. - doi: 10.1046/j.1365-294X.2002.01 611. $\mathrm{x}$

Mendoza I, Zamora R, Castro J (2009). A seeding experiment for testing tree-community recruitment under variable environments: implications for forest regeneration and conservation in Mediterranean habitats. Biological Conservation 142: 1491-1499. - doi: 10.1016/j.biocon.2009. 02.018

Meyer SE, Allen PS (1999). Ecological genetics of seed germination regulation in Bromus tectorum L. I. Phenotypic variance among and within populations. Oecologia 120: 27-34. - doi: 10.100 7/s004420050829

Meyer SE, Kitchen SG, Carlson SL (1995). Seed germination timing patterns in intermountain
Penstemon (Scrophulariaceae). American Journal of Botany 82: 377-389. - doi: 10.2307/2445 584

Moreira F, Viedma O, Arianoutsou M, Curt T, Koutsias N, Rigolot E, Barbati A, Corona P, Vaz P, Xanthopoulos G, Mouillot F, Bilgili E (2011). Landscape-wildfire interactions in southern Europe: implications for landscape management. Journal of Environmental Management 92: 2389-2402. - doi: 10.1016/j.jenvman.2011.06.028 Muñoz M (1986). Cultivo de embriones y ensayo de germinación en boldo (Peumus boldus Mol.) [Embryo culture and germination essay in Boldo (Peumus boldus Mol.)]. Undergraduate thesis, Facultad de Ciencias Agrarias y Forestales, Universidad de Chile, Santiago, Chile, pp. 88. [in Spanish].

Nishitani S, Masuzawa T (1996). Germination characteristics of two species of Polygonum in relation to their altitudinal distribution on $\mathrm{Mt}$. Fuji, Japan. Arctic and Alpine Research 28: 104110. - doi: 10.2307/1552092

O'Toole JC, Cruz RT (1979). Leaf rolling and transpiration. Plant Science Letters 16: 111-114. - doi: 10.1016/0304-4211(79)90015-4

Pausas J, Llovet J, Rodrigo A, Vallejo R (2008). Are wildfires a disaster in the Mediterranean basin? A review. International Journal of Wildland Fire 17: 713-723. - doi: 10.1071/WF07151

Roach DA, Wulff RD (1987). Maternal effects in plants. Annual Review of Ecology and Systematics 18: 209-235. - doi: 10.1146/annurev.es.18.1101 87.001233

Schulz JJ, Cayuela L, Echeverria C, Salas J, Benayas JMR (2010). Monitoring land cover change of the dryland forest landscape of Central Chile (1975-2008). Applied Geography 30: 436-447. - doi: 10.1016/j.apgeog.2009.12.003

Tripathi RS, Khan ML (1990). Effects of seed weight and microsite chraracteristics on germination and seedling fitness in two species of Quercus in a subtropical wet hill forest. Oikos 57: 289-296.

Van Der Vegte FW (1978). Population differentiation and germination ecology in Stellaria media (L.) Vill. Oecologia 37 (2): 231-245. - doi: 10.1007/ BFo0344994

Vander Mijnsbrugge K, Bischoff A, Smith B (2010). A question of origin: where and how to collect seed for ecological restoration. Basic and Applied Ecology 11 (4): 300-311. - doi: 10.10 16/j.baae.2009.09.002

Vogel H, Razmilic I, Doll U (1997). Essential oil and alkaloid contents of different populations in boldo (Peumus boldus Mol.). Ciencia e Investigación Agraria 24:1-6. 